\title{
The Duke's Parrot: The earl of Leicester, the king's children and the English revolution
}

\author{
Jason Peacey
}

UCL

This article examines neglected evidence regarding the ongoing captivity of the children of Charles I, at the hands of the republican regime, long after the regicide in January 1649. Thus, while it is well known that the Long Parliament was anxious to attend to the education of the royal children, and to exert authority over their upbringing, and also that there were rumours during the 1640s about plans to install the youngest prince, the duke of Gloucester, on the throne in place of a deposed king, little attention has been paid to voluminous and intriguing evidence about their fate during the interregnum. The aim of this essay is thus to survey such sources, and to recover evidence that there was an ongoing political and parliamentary debate about the children's fate, not least in a situation where it was thought possible that they might provide a rallying point for royalists, and a security threat. That debates about their fate were protracted and convoluted is used to flesh out rather sketchy evidence - much commented upon by historians, but not taken very seriously - that there was an ongoing debate over a possible monarchical settlement until 1653.

Keywords: Charles I; Henry duke of Gloucester, Princess Elizabeth Stuart; regicide; republic; political factions; monarchy.

Jason Peacey is Professor of Early Modern British History at UCL, and is the author of Politicians and Pamphleteers. Propaganda in the Civil Wars and Interregnum (2004), and of Print and Public Politics in the English Revolution (2013). He also edited The Regicides and the Execution of Charles I (2001) and The Print Culture of Parliament, 1600-1800 (2007), and co-edited Parliament at Work (2002). He is currently working on Anglo-Dutch political culture in the seventeenth century, with a particular focus on the diplomacy of print and news, and overlapping and interlocking publics.

On 30 July 1649, a servant of the countess of Leicester, Miles Smyth, recorded in his accounts having paid one Tom Elliott $1 s .6 d$. 'for carrying the duke's parrot from Sion to Southwark'. 'The Duke' was Henry, duke of Gloucester, the third son of the recently executed Charles I, and the transportation of the parrot came about as the nine year-old duke, like his thirteen year-old sister, Princess Elizabeth, was transferred from the control of the earl of Northumberland to the care of the earl's sister, the countess of Leicester, at Penshurst in Kent. It was but one entry in a fascinating set of accounts that shed remarkable light upon 
the children's life between their arrival at Penshurst on 14 June 1649 and their subsequent move to the care of Anthony Mildmay at Carisbrooke Castle, in early August 1650. It is possible to observe repeated payments for 'the princess to play’ (usually at $£ 2$ ), as well as payments to get her supplies of cake, oranges and lemons. Her wardrobe was replenished, which meant that her petticoats were mended, and that purchases were made of scarlet galloon (12s.), scarves, powder, bodices, shoes, combs, gloves, ribbons and other 'stuffs'. In March 1650, Mrs Briott was paid 18s. to supply Elizabeth with a gorget, cuffs, peaks and a border. The princess was also provided with pins, serge and silk by 'Robin the Welshman', so that she could do her sewing, and then with a battledore and shuttlecocks so that she could play with her brother and the young Henry Sidney, the future earl of Romney, who was only a few months younger than the duke. Elizabeth's more lavish tastes, meanwhile, were accommodated by payments to mend her watch $(2 s$.$) , to buy crystal (£1 15 s$.$) , and perhaps$ also to buy jewellery. The sum of $£ 50$ was paid to one Mr Crompton for twenty diamonds, for setting a diamond and a great ruby, and for polishing rings. In November 1650, a further $£ 28$ was spent on a ruby ring set with diamonds.

The duke, meanwhile, was provided with all manner of goods, from the trivial to the luxurious. These included 'a comb and a puff', laced bodices (over £1), shoes, stockings, gloves and a leather cap, as well as periwigs, complete with boxes, powder and combs. In November 1649 he received a 'sad coloured cloth coat, a black suit and a velvet coat (£13 $8 s$. $6 d$.), and in March 1650 he got two new suits and a cloak (£10 1s.), and then a black serge suit in July 1650 ( $£ 39$ s.). His old hat was lined, and he was given a new beaver hat with a case ( $£ 216 s$.), and then another one a few months later ( $£ 212 s$.$) . He was given knives, bowls$ and a standish. Mr Peaker was paid $£ 1$ for shaving him. Attention was paid to his education; his tutor Richard Lovell, whom Clarendon called 'an honest man', apparently ensured that he was 'well taught in that learning that was fit for his years'. Lovell thus spent $£ 28 s .4 d$. on 
books for his young charge in October 1649, and a further $£ 1$ in August 1649, and also acquired a pair of globes and thirteen maps, at a cost of $£ 22 s$. At the same time, the duke engaged in a range of other pursuits. His pistol was mended, and he was given a bow, quiver and arrows, the latter at a cost of 30s. He received riding boots and spurs in November 1649 (£1 12s.). He hunted deer, and was given a greyhound, the messenger who brought which was given $5 s$. The duke and princess were also entertained with jugglers and fiddlers, treated to at least one masque (which cost at least £5), and made at least one trip to the bowling green. They each also had their own servants, including footmen, grooms and laundry maids, and these two were provided with equipment (smoothing irons), repaid their expenses (such as for travelling to Cobham and Petworth), and paid their wages (over £120 per annum), and also provided with suits, livery and laced coats, hats, stockings and shoes, all of which cost over $£ 40 .^{1}$

Smyth's accounts, in other words, provide and intriguing picture of the way in which the duke of Gloucester and Princess Elizabeth were maintained in the months after the execution of their father Charles I, but they also open up interesting issues relating to the politics and culture of the English republic, which have received little attention, and which relate very closely to the extraordinarily valuable work that Clyve Jones has done to address the role of the nobility in early modern politics. The duke and his sister have been more or less overlooked, at least until quite recently, perhaps because both met with early deaths. Familiar, of course, is the story about the duke being granted access to his imprisoned father on 7 January 1649, and it is also known that in the days between Charles I's execution and his burial the young republic provided the duke with two chambers hung with black cloth (1 February 1649). We know that Elizabeth died in the summer of 1650, and that Henry, having eventually made his way to the continent, returned to England with his elder brother, Charles II, in May 1660, took his seat in the house of lords, only to die of smallpox in the following 
September. ${ }^{2}$ What is less well understood, however, is the thinking behind their treatment by the commonwealth regime after the death of Charles I, the decisions that were made, and what these might mean, not least given that they - like Charles's other children - had long been a political issue of real importance.

What seems clear, therefore, is that the fate of the king's children had been in play since the early 1640s, when the 'Ten Propositions' demanded 'that some persons of public trust and well-affected in religion may be placed about the prince who make take some care of his education, and of the rest of his children, especially in matters of religion and liberty', and when the 'Nineteen Propositions' insisted that 'he or they unto whom the government and education of the king's children shall be committed shall be approved of by both houses of parliament'. ${ }^{3}$ As contemporaries recognised, therefore, the royal children were a bargaining chip, and when the Venetian ambassador Giustinian noted in November 1642 that the 'little duke of Gloucester' and his sister had been moved from the fringes of London to a house at the heart of the capital, he mocked the idea that this had been done to protect them from harm amid possible fighting as a 'specious pretence'. He detected, indeed, a 'secret design' on the part of parliamentarians 'to avail themselves of these innocent victims as hostages if the king comes back victorious to his residence here, as they feel persuaded that the precious pledge of these children will serve them in the utmost peril as an opening to obtain a pardon from his majesty more easily, as well as safety for the persons and the fortunes as well of the rebels'. ${ }^{4}$

What is also clear is that decisions about who should look after the king's children once war broke out were carefully thought through. Initially, therefore, the Commons had proposed that they should be looked after by lady Vere, 'an old lady much in their favour' according to Clarendon, only for the house of lords to object, and for it to become clear that she was 'not at all ambitious of that charge'. As such, it was agreed that the children should 
fall under the care of the countess of Dorset, the wife of a moderate royalist peer, before eventually being entrusted in March 1645 to the earl of Northumberland, a parliamentarian grandee of huge importance, complete with a maintenance of $£ 3,000$ per annum. ${ }^{5}$ In keeping with the Nineteen Propositions, moreover, plans were laid for the royal children to have a godly education. During the mid-1640s, therefore, their household servants included a raft of puritan divines, such as Obadiah Sedgwick, Joseph Caryll, Jeremiah Whitaker, William Greenhill, William Spurstow, Samuel Torshell and Stephen Marshall, the latter of whom was noted in the royalist press has having delivered monthly lectures to the captive children. ${ }^{6}$

Given such evidence about the importance that parliamentarians attached to the king's children and their governance, there are grounds for revisiting the fate of the only two members of the royal family who remained under parliamentarian control following the escape of the duke of York from St James's Palace in the spring of 1648, particularly given that the duke of Gloucester remained in custody long after the execution of Charles I, until his eventual release in early 1653 . By tracing the story of the royal children after January 1649 - when Gloucester was allowed to visit his father, on the same day that parliament ordered that nobody was to be proclaimed king 'without the free consent of the people in parliament $^{7}$ - it will be possible to suggest that the complex dynamic of their captivity reflected serious - if cloudy - debates about their fate. These debates, moreover, bear serious scrutiny in the light of recent historiography regarding events leading up to the regicide, and in order to question problematic accounts offered by Venetian onlookers and contemporary royalists like the earl of Clarendon. 
Clarendon's account of the duke of Gloucester and Princess Elizabeth revolved around the idea that, following the escape of the duke of York 'the parliament would not suffer, nor did the earl desire, that the rest should remain longer under his government', and that the children were immediately treated with less respect than they warranted. ${ }^{8}$ What actually seems clear is that this is a dramatic oversimplification. Northumberland was cleared of any blame for the duke of York's escape, and remained governor of the remaining royal children until after the regicide. ${ }^{9}$ More importantly, the months after the death of Charles I were marked by real uncertainty regarding the fate of the king's younger children. On 1 February the committee dealing with the issue of the king's body was ordered to provide two chambers, hung with black, for Gloucester. ${ }^{10}$ On 23 February 1649, Sir Henry Mildmay was ordered to report regarding the issue of their allowance, but what is remarkable is how little was said or done about them during the weeks that followed, even as it was finally decided to abolish the monarchy on 17 March. ${ }^{11}$ Only in early April did the question of what to do with the prince and princess arise in earnest, following the decision by the earl of Northumberland to resign as their guardian, in a letter which was ordered to be reported to the Commons by Lord Lisle on 9 April. ${ }^{12}$ That there was uncertainty about how to proceed at this juncture seems clear from the fact that this report was actually only delivered on 24 April, when the Commons resolved to consider it the following day as a matter of real importance, 'nothing to intervene' ${ }^{13}$ At this point - and perhaps in response to more than one letter from Princess Elizabeth - it was agreed to continue paying $£ 3,000$ per annum for the maintenance and education of the two royal children, while the committee of revenue was to consider what money remained due to Northumberland and to the children's servants for wages and arrears. $^{14}$

Apart from the fact that there is no evidence of any discussion about the wisdom or necessity of the republic providing for the children of the executed king, what also emerges at 
this point is that at least some thought was given to the possibility of allowing the children to travel to their family on the Continent, with or without ongoing financial support from parliament and council of state. Whether or not Elizabeth asked for a pension, therefore, she may also have asked for liberty, and when these letters were considered on 25 April the question was posed that she at least should be allowed to travel abroad. That this was contentious, however, is evident from the fact that the House promptly divided, and that a vote was forced. On this occasion the yeas (whose votes were recorded by Sir William Masham and Sir William Allenson) were narrowly defeated by the noes (whose votes were reported by Sir Michael Livesey and Sir William Brereton), 29 to 24. It was decided, albeit only narrowly, that Elizabeth should stay under parliamentary control, and it is significant that there seems to have been no question at this stage that the duke should be allowed out of the country. ${ }^{15}$

Thereafter, however, uncertainty remained. The initial idea was that the two children should be placed under the care of Sir Edward Harrington, for whom the council started to prepare instructions, while Lord Lisle was asked to notify the earl of Northumberland. ${ }^{16}$ Harrington, however, declined the role, pleading sickness (27 April), ${ }^{17}$ and it was not until 24 May that it was decided that the children should be sent to Penshurst, under the care of Northumberland's sister, the countess of Leicester, who would receive their maintenance money, instructions once again being given to Lord Lisle to convey the news to his mother, the countess, and his uncle, Northumberland. ${ }^{18}$ The Penshurst accounts record payment of $7 \mathrm{~s}$ for a copy of the order of 24 May, and both Northumberland and the countess engaged in negotiations with the committee of revenue (11 June). ${ }^{19}$ There then ensued inevitable bureaucracy, noted in the Penshurst accounts in terms of payments to clerks and secretaries for copies of orders, and in terms of the cost of making repeated journey by water to Westminster. ${ }^{20}$ Eventually, however, the children were indeed taken to Penshurst, on 14 June, 
as noted in Leicester's diary, ${ }^{21}$ a job that involved transporting 77 hundred weight of goods, at a cost of almost $£ 10 .^{22}$ Thereafter, the accounts reveal regular receipts of $£ 250$ per month, beginning on 16 June, transactions that were handled by a trusty servant called William Hawkins, whose legal and clerical fees and gratuities - to Cozens and his clerk, and to $\mathrm{Mr}$ Sherwyn - were also recorded. ${ }^{23}$

Such evidence alone is insufficient to establish the thinking behind the decision to keep both children in England, although it is noteworthy that the earl of Leicester considered the business 'troublesome', and referred to a 'huge storm' over the costs involved. ${ }^{24}$ Fortunately, other evidence about their treatment at Penshurst makes it possible to at least go some way towards dealing with such issues. First, it is possible to offer somewhat qualified support for Clarendon's claim about the way in which the royal children were treated. Clarendon claimed, therefore, that previously the children had been awarded money 'as might well defray their expenses with that respect that was due to their births', and that Northumberland 'received and treated them in all respects as was suitable to their birth and his own duty', even if he could 'give them no more liberty to go abroad than he was in his instructions from the parliament permitted to do'. ${ }^{25}$ Clarendon also added, however, that this was 'performed towards them as long as the king their father lived', and that thereafter this allowance was 'retrenched', so that their attendants and servants might be lessened. This seems not to have been the case in financial terms, although Clarendon correctly noted that 'order was given that they should be treated without any addition of titles, and that they should sit at their meat as the children of the family did, and all at one table'. Here, therefore, Clarendon picked up on instructions issued on 13 June 1649, whereby the children were to sit with the earl and countess 'at their table, as part of their family, and not otherwise', and that 'no other observance or ceremony be used to the late king's children, than is used to noblemen's children of this nation' ${ }^{26}$ Clarendon's comment was that the royal children were 
'carefully looked to, and treated with as much respect as the lady pretended she durst pay to them', and what seems fairly clear is that, lavish though the lifestyle of the duke and princess seems to have been, they were treated as noble rather than royal children. ${ }^{27}$ It is notable, therefore, that the kind of money that was spent on them was similar too, done in the same way as, and paid at the same time as, money was spent on young Henry Sidney. The two young boys, indeed, were brought up in the same way; they not only played together, but received the same clothes and toys, and received the same education. Of course, Penshurst was a grand house, and the earl and countess certainly lived a lavish lifestyle, as is clear from other entries in the accounts, not least in relation to art work. On 7 May 1649, therefore, one Mr Geldrup was paid $£ 7$ for a copy of the earl of Sunderland's picture, while Mr Stone was paid $£ 12$ for 'a copy of the large Venus’. Between April and December, moreover, the family paid Sir Peter Lely $£ 25$ for two pictures of Henry Sidney. ${ }^{28}$

If the duke and princess were deliberately treated as members of the nobility, but not as royalty, then what also seems clear is that the decision to place them at Penshurst reflected nervousness about their potential visibility. Here too, however, Clarendon's account was rather simplistic. He was wrong to say that the children were moved 'as soon as the king was murdered', although perhaps right to claim that the order 'that the children should be removed into the country' reflected a concern 'that they might not be the objects of respect, to draw the eyes and application of people towards them' ${ }^{29}$ Here, therefore, it seems plausible to conclude that the move to Penshurst was an attempt to restrict the visibility of the royal children, in the face of their capacity to elicit sympathy. Indeed, it is possible that such concerns had been evident much earlier. A recommendation by the Lords in July 1647, that the children should be removed from London to one of Northumberland's country residences (Syon House), was ostensibly made in the interest of their health, but this may merely have been a veil for concerns about their popularity. Living at Syon made it possible for them to 
visit the king at Hampton Court, but it also placed them out of sight a particularly tense moment in the capital, and evidence from May 1648 certainly reveals that they were capable of drawing a crowd in places like Hyde Park, where many people apparently came to kiss their hands. ${ }^{30}$

Such evidence suggests that Clarendon's account was somewhat simplistic, and that the authorities were grappling with something of a conundrum, rather than merely downgrading the children's status and preventing them from attracting public attention and popular sympathy. Parliament and the council of state made conscious decisions about what kind of respect to show to the royal children, and to categorise them as members of the nobility (but nothing more), and there does indeed seem to have been a concern that they might attract attention from a public still adapting to the new republic, and become rallying points for royalist agitation. Nevertheless, the delay in making decisions about what to do with them until late May 1649 also signals uncertainty about how best to proceed, and about what a long term solution might be. According to the Venetian ambassador, therefore, the decision to send the children to Penshurst was a temporary measure, 'until other arrangements were made by the Commons'. ${ }^{31}$ There was at least some consideration given to the possibility of their being released, although it is notable that this was more obviously considered to be an option for Princess Elizabeth than for the young prince, and there was much more obviously a resolve to keep the duke of Gloucester in England. Indeed, the significance of a curious story told by Lord Hatton, about delayed attempts to effect the duke's escape in January 1650, reflects not just on the strange behaviour of key courtiers Hatton wrote of 'strange diffidence of those about the king', and of one 'of nearest trust' to the duke complaining that an attempt being 'spoiled' - but also on the attitude of the republican government. Hatton noted, therefore, that notice was given to the earl of Leicester to 'look about him and take heed of a design in this kind' - by someone 'in place about his 
majesty' - which would seem to signal a resolve on the part of the duke's captors to keep him in their custody. ${ }^{32}$ Such themes, and a sense of contemporary debate about what to do with the duke of Gloucester, come into sharper focus by exploring the next phase of his captivity.

II

That Penshurst was considered to be an imperfect solution to questions surrounding the duke of Gloucester is clear from the events in the summer of 1650, which saw the royal children moved from Penshurst to Carisbrooke Castle on the Isle of Wight, although once again the evidence suggests that Clarendon's account is more or less deficient, that this phase in their captivity raises important issues and challenges, and that the authorities were uncertain, and perhaps conflicted, about what to do. The new regime certainly made some fascinating decisions, influenced by concerns about security, as well as by considerations about whether or not to keep the children - and particularly the duke - in captivity.

Most obviously, the republican government demonstrated ongoing concern about the risk that the Duke would provide a rallying point for royalists, not least in the wake of the arrival of Charles II in Scotland on 23 June 1650. On 24 July, therefore, the Commons heard a report from the Council of State - delivered by Sir Henry Mildmay - to the effect that because of 'many designs now on foot, if any stirrings or insurrections should happen, the public peace would be much more endangered, by occasion of the late king's children, who are here remaining, who may be made use of to the prejudice of the public'. As such, the council urged parliament to think of a 'remedy'. What is significant, however, is that at this stage it was debated whether both Elizabeth and Henry should be 'removed beyond the seas, out of the limits of this commonwealth'. Indeed, this was duly agreed, and the council was ordered to consider a 'fit place' and suitable maintenance 'beyond seas'. ${ }^{33}$ Only subsequently 
was it decided - on 27 July - that they should be sent to Carisbrooke, and placed under the custody of Sir Henry Mildmay's brother, Anthony Mildmay, with a similar maintenance and with up to eight servants (of the children's own choosing), after instructions had been issued, and after both the countess of Leicester and the earl of Northumberland had been notified. Arrangements for their transportation and maintenance were discussed in special sessions of the council in the days that followed, and Major General Thomas Harrison was deputed to make arrangements, 'the port, way, manner and convoy being wholly left to him'. Intriguingly, this order was passed on the very same day that statues of both James I and Charles I were ordered to be removed from London 'by having their head taken off'. Ultimately this involved Mildmay collecting the children from Penshurst on 9 August, and conveying them by two coaches, with six horses apiece, 'for their better accommodation', and it was noted that this was all to be done 'privately' and without 'ceremony', with an eye to security. ${ }^{34}$

As with the move to Penshurst, Clarendon saw this transfer to Carisbrooke as part of a calculated process by which the status of the royal children was downgraded. Noting that they were to be provided with maintenance, therefore, Clarendon claimed that 'in truth', this was given to Mildmay 'as a boon to him'. ${ }^{35}$ In fact, it seems clear that the state merely transferred over to Mildmay the same funds that had been assigned to Northumberland - i.e. $£ 3,000$ per annum - along with all of the goods that had been supplied for them at Penshurst. Once again, Clarendon was closer to the mark in noting that strict requirements were put in place 'that no person should be permitted to kiss their hands, or that they should be otherwise treated than as the children of a gentleman'. What this meant in practice, according to Clarendon, was that Mildmay, in observing his instructions 'very strictly', referred to the duke as 'Mr Harry'. ${ }^{36}$ Mildmay's official instructions had indeed indicated that he was 'not to suffer any other ceremony... than what is fit for and due to a gentleman, neither at table, nor 
in the journey, nor otherwise'. The children were to be placed under guard, to be supplied by the governor of the Isle of Wight, Colonel William Sydenham, while Mildmay was empowered to displace any servants as he saw fit. ${ }^{37}$

Beyond this issue of their treatment, evidence from the months that followed suggests that the authorities remained conflicted over where exactly the children should reside, whether or not to grant them liberty, and whether or not to treat the two siblings differently. On 20 August, therefore, at the same time as the council responded to a letter from Anthony Mildmay by ordering an inventory of all the goods that had been sent to Penshurst by Northumberland, in order to ensure that the children would have 'things necessary, provided all be included in the sum of $£ 3,000$ per annum’, Sir Henry Mildmay was ordered to move them 'to such place as they are most willing to go, they being appointed by parliament to be transported out of the limits of the commonwealth'. Perhaps Carisbrooke, in other words, was only seen as a temporary residence..$^{38}$

In the face of Elizabeth's illness, for example, it was certainly thought possible that she might be released. On 5 September 1650, therefore, after the victory over the Scots, it was reported to parliament that since her transfer to Carisbrooke Elizabeth's health had deteriorated seriously, and she was described as being 'indisposed'. As such, the council of state agreed to her request to be able to go to her sister, the princess of Orange, and ordered that she should receive $£ 1,000$ per annum, 'so long as she shall behave inoffensively to the parliament and commonwealth' ${ }^{39}$ That this did not in fact happen merely reflected her worsening condition, which prompted Mildmay to send for her doctor, despite there being 'little hope of life amid many signs of imminent death'. Indeed, Elizabeth died within a matter of days, and was buried on 24 September, the committee of revenue being ordered to make arrangements for the funeral, which saw the duke of Gloucester and the royal servants being providing with mourning attire. ${ }^{40}$ 
Interestingly, however, there seems to have been at least some support by this stage for the idea of letting Henry leave too. On 5 September, therefore, it was decided that Henry should be sent to brother, Charles II, in Scotland and have $£ 1,000$ per annum on similar terms to his sister, 'so long as he behave inoffensively'. ${ }^{41}$ This might indeed have happened, one suspects, had it not been for the timing. Thus, while Sir Henry Mildmay reported the council's view to the Commons on 11 September, parliament evidently thought it more appropriate, in the wake of the battle of Dunbar, to send the young duke to the University of Heidelberg, accompanied by three servants of his choice, and supported by $£ 1,500$ per annum. ${ }^{42}$ A council committee, comprised of Mildmay, Thomas Chaloner and Thomas Scot was charged with finding the 'best way' that this might be achieved, and to organise instructions and financial arrangements, while the admiralty committee was ordered to provide a ship. ${ }^{43}$ Subsequently, on 26 September, Mildmay was asked to confer with Fauconbridge regarding the finances, while Walter Frost was ordered to confer with local merchants in Heidelberg about arranging bills of exchange, in consultation with Mildmay, Chaloner and William Heveningham. ${ }^{44}$ This plan was still on the cards, moreover, in early October 1650, when the council agreed to allow one Mr Fitzwilliams to accompany the duke to Heidelberg, when the orders were renewed for the admiralty committee to find a suitable ship, and when Thomas Scot, Edmund Ludlow and Sir William Constable were added to the committee to oversee the duke's departure (11 October). ${ }^{45}$ By 18 October, however, when Chaloner was ordered to report to parliament on progress regarding such proceedings, the council had decided that the situation north of the border had changed sufficiently for the duke to be sent to Scotland after all. ${ }^{46}$ Perhaps such thinking was encouraged by a letter from Anthony Mildmay, in mid-November 1650, in which he referred to the Isle of Wight as a 'bleak and cold' place in winter, and to the fact that the poor air might be prejudicial to the duke's health. ${ }^{47}$ More likely is the possibility that concerns remained about the duke as a 
security threat. On 30 November, therefore, the council signalled its intention to write to Anthony Mildmay to express concern that the duke's 'going up and down in the Isle of Wight may be of dangerous consequence to the peace of the nation in regard of the insurrections already begun'. As such, he was ordered to be kept within Carisbrooke Castle. ${ }^{48}$

Even at this stage, however, the duke was not released; he remained at Carisbrooke, and Mildmay continued to receive his allowance, although ongoing concerns about his behaviour, and about the possibility that he might attract unwanted attention occasionally led to renewed interest in the possibility that he should be 'disposed of to some other place than the Isle of Wight', including Scarborough, as in early June 1651 and again in the following August. ${ }^{49}$ In late November 1651, meanwhile, the council reported to parliament that if the Commons 'think fit to continue him there' something would need to be done to provide him with 'necessary accommodation', given the zeal with which the contractors for the sale of the late king's goods had been asset-stripping the castle. ${ }^{50}$

Such evidence seems to indicate uncertainty and divided opinions over the duke's fate, although perhaps not quite the dynamic that Clarendon tried to fathom in the run up to his eventual release in early 1653 . In seeking to explain this outcome, therefore, Clarendon mused that it reflected the fact that Cromwell was 'jealous' that the duke - whom he described as 'a prince of extraordinary hope, both from the comeliness and gracefulness of his persons and the vivacity and vigour of his wit and understanding' - might 'be made use of by the discontented party of his own army to give him trouble'. Clarendon also considered the possibility, however, that Cromwell merely sought to 'show the contempt he had of the royal family, by sending another of it into the world to try his fortune'. Whatever the logic of Clarendon's reasoning, his account is interesting because of his suggestion that Cromwell did 'declare one day to his council that he was well content that the son of the late king... should have liberty to transport himself into any parts beyond the seas as he should desire', and 
because this was said to have been 'much wondered at, and not believed, and many thought it a presage of a worse inclination'. As such, Clarendon noted, 'for some time there was no more speech of it'. ${ }^{51}$ Thereafter, Clarendon claimed, the impetus for releasing the duke came most obviously from the prisoner himself, who was informed about such machinations 'by those who wished his liberty', people who encouraged him to 'prosecute the obtaining that order and release'. As such, according to Clarendon, the duke sent Lovell to London, 'to be advised by friends what he should do to procure such an order and warrant', adding that Lovell 'did so dextrously solicit it' that he eventually secured precisely such a warrant on 17 January 1653 , together with $£ 500 . .^{52}$

As on other occasions, Clarendon's account is intriguing, but not entirely convincing. Lovell had certainly demonstrated a willingness to lobby on the duke's behalf. In October 1650, for example, the council of state ordered Chaloner and Scot to consider a petition from Lovell and John Griffith, and to grant them an allowance during their stay in London, out of the $£ 1,500$ which had been assigned to effect the duke's transportation overseas. ${ }^{53}$ In March 1652, Lovell had also complained about delays in paying the duke's maintenance, saying that this caused 'great difficulty in making daily provision', and thereby effecting the payment of arrears. ${ }^{54}$ However, it seems likely that the machinations to which Clarendon referred involved hard thinking on the part of Cromwell and his colleagues, and decisions that proved difficult and perhaps divisive. In what may have been the incident to which Clarendon referred, therefore, the Council resolved on 7 September 1652 to consider how to dispose of the duke, although the matter did not resurface until 6 December, when the lord president was ordered to move parliament that 'considering the state of affairs' the duke should be moved 'to some other place', as the Commons saw fit. ${ }^{55}$ It was at this stage that the idea really gained momentum. On 7 December parliament issued an order for the duke to be removed from the Isle of Wight; three days later the matter was taken up by the council; and on 13 
December the committee for foreign affairs was ordered to consider the place to which the prisoner should be sent, and what accommodation would be fit. ${ }^{56}$ Within a matter of days, moreover, the council had resolved to ask the duke himself 'the place in France or Flanders where he desires to be landed and the persons he chooses to attend him', and its committees considered issues relating to money and transport, and resolved to provide him with $£ 400$ to cover the cost of his journey to Dunkirk or Ostend, and to pay any unpaid bills on the Isle of Wight. The duke was also to have Antwerp bills of exchange to the value of $£ 1,000$, alongside a ship and four servants, as well as 'necessaries', and the duke authorised Lovell to receive such money on his behalf, and to organise the journey, with the approval of Mildmay and Sydenham. ${ }^{57}$ What Clarendon did not consider, but what the Venetian ambassador certainly noticed, was that this flurry of activity coincided with fears regarding a possible Dutch attack on the Isle of Wight. On 27 December, therefore, the ambassador noted that although the island was 'in a good state of defence',

they have considered it advisable to order the removal thence of the duke of Gloucester... who has been kept prisoner there a long while. It is not known what they mean to do with him now. Some say that he will be allowed, if he likes, to go to his cousin, the count Palatine in Germany, parliament paying him an annual pension. Others assert that they mean to give him $£ 1,000$ sterling and desire him to leave England and go where he pleases. ${ }^{58}$

It should also be noted that at precisely this time the council considered Sydenham's proposals for improving the island's fortifications. ${ }^{59}$

Even at this late stage, however, things did not run entirely smoothly, despite efforts to secure a vessel with the help of the admiralty committee, the passing of an order to issue 
the duke with a pass (on 14 January) and to organise his finances, and the issuing of such a warrant on 17 January. ${ }^{60}$ As late as the first week of February, therefore, Sydenham was forced to report to the council that, although Lovell had procured a vessel to take the duke to Flanders, Anthony Mildmay refused to release him, claiming not to have been formally discharged of his trust. Referring, indeed, to 'this unexpected forcible stop', Sydenham explained that Mildmay was keeping the duke locked up within his own lodgings, and he obviously sought to deny any responsibility. Indeed, he also enclosed a letter to the council from the duke himself, who acknowledged the 'many favours' he had received, and expressed thanks for being allowed to travel abroad, but who asked that the council would be 'pleased to assert your own act'. The duke explained, therefore, that Mildmay 'has not only taken resolution to stay me and to that purpose refused to accommodate me with a bed, or blanket, or any utensil to carry on shipboard, but locks his door upon me, and denies me to talk about the castle, or to enjoy that liberty which you have always granted me, unless he be forced to it by arms or a particular order from you'. He noted, indeed, that Mildmay had seen a copy of the council's warrant, 'but is not satisfied'. ${ }^{61}$ As a result, the council decided to write to Mildmay on 4 February, ordering him not to 'hold Henry Stuart in restraint'. As such, on 12 February Sydenham was finally able to report that the council's orders had been executed, and that the duke had set sail from Cowes the previous day. ${ }^{62}$

This curious episode is important because it shines a light on issues that had almost certainly been in play since the spring of 1649. First, Sydenham confirmed fears that had always surrounded a captive member of the Stuart family, namely that he would provide a rallying point for royalist sympathisers. Thus, while Sydenham sought to ensure the government that the duke slipped away 'without much notice or observance', he was forced to admit that 'some private men of war in the road were more free in their salutes than became them'. ${ }^{63}$ Such expressions of respect for the duke duly provoked an investigation by 
the council into who might have been responsible. ${ }^{64}$ Indeed, nervousness about the duke persisted even after his departure from the Isle of Wight, not least when Lovell approached the mayor of Dover on 14 February for permission to come ashore and take refreshment, the duke having become ill as a result of contrary winds and a 'distemper at sea'. The mayor, William Cullen, as well as the town's governor, duly agreed to this request, but only when Lovell promised that the duke would rest privately at the house of one Mr Delavall, and that nobody would be allowed to visit him, 'whereby anything should be done prejudicial to the commonwealth'. It is also interesting that, having granted the duke this civility, Cullen sought reassurance from the council that he had not done anything untoward. Secondly, the duke's letter to the council indicated more than just that Mildmay was being punctilious in the absence of the original warrant, and he intimated awareness that the issue of his release had 'long endured dispute and now suffers resistance also', and that there were 'many threats to hinder my going', ${ }^{65}$

III

Eventually, of course, the duke made it to Dunkirk, before heading to Antwerp and the Hague, amid reports that he had been 'exiled by parliament there on pain of death if he ventures to return', and that he had been sent out of the country 'to prevent any possible inconvenience that his presence... might cause the commonwealth' ${ }^{66}$ What quickly became apparent was what parliamentarians had always feared: that without proper guidance he would fall into the clutches of papists and be converted to catholicism, and even be made a cardinal. By May, therefore, he had reached Paris, to be greeted by his mother 'who left him in England a mere baby', and when Charles II discovered how Henrietta Maria intended to have him educated, he sent Ormond to try and dissuade her, prompting the Venetian 
ambassador to suspect that 'the project will be dropped, and the princes of the house of Stuart, after having been expelled from the kingdoms of this world, will now submit to banishment from the kingdom of heaven' ${ }^{67}$ What merits reflection, however, is what to make of this complex and protracted story of the process which culminated in the duke being reunited with his less than united family.

What seems clear, therefore, is that whatever role was played by 'civility' in supporting young members of the royal family who had played no part in the civil wars, there was deeper significance to decisions about where the duke and princess should be detained, and to whom their care should be entrusted. There can also be no doubt that the republican regime thought fairly carefully about how the royal children should be treated, and about how much respect they should be afforded, and it is hard not to conclude that the machinations surrounding their captivity revealed uncertainty over whether to detain them or whether to release them. What emerges, indeed, is that given the fear that they might become a rallying point for disaffected royalists, and that keeping them hidden was more or less difficult, not to say expensive, it might have been easier to let them go. At certain points, indeed, at least some contemporaries thought that this would be the best option. All of which begs the question: what possible reason was there to keep them in custody?

My suggestion is that answering this question requires reflecting on earlier ideas and rumours regarding the duke, which had been common currency since the early 1640s, and which involved the notion that he could be placed on the throne as a puppet king in place of a deposed (or indeed executed) Charles I. As early as October 1643, therefore, the earl of Bath reported a story that parliamentarians planned to make the duke 'constable of England' and 'then manage the war in his name', while the royalist press even suggested that Henry Marten threatened to seize the crown jewels in order to 'crown his majesties youngest son'. ${ }^{68}$ Later, in March 1645, the Venetian ambassador reported that if Charles I refused to come to terms, 
parliamentarian leaders would place the crown on the young duke's head, and make Northumberland protector. ${ }^{69}$ This was an idea that refused to die, and in January 1646, as news of the Glamorgan treaty provoked strong words against the king in parliament, thoughts once again turned to the possibility of deposing Charles. According to the French ambassador, therefore, it was mooted that the prince of Wales would be declared an enemy of the state, and that if the duke of York refused an official summons to return to London, the 'little duke of Gloucester' would be crowed, under the protectorate of the earl of Northumberland. ${ }^{70}$ In the following July, meanwhile, another French ambassador arrived in London to reports that the Independents would set the duke on the thrown for a year or two, before declaring a republic. ${ }^{71}$ Such rumours were what underpinned Charles I's warning to his youngest son, that he might become 'an instrument' to achieve the 'wicked designs' of Independent grandees, and that if he himself was killed 'they might possibly... make him king, that under him, whilst his age would not permit him to judge and act for himself, they might remove many obstructions which lay in their way, and form and unite their councils, and then they would destroy him too'.72

Such rumours and stories persisted into the late 1640s, not least as the escape of the duke of York led parliamentarians to reiterate their support for a monarchical government, ${ }^{73}$ and as contemporaries noted that 'they have not decided how, by what particular means they shall reach this end and whether they shall have for king... the duke of Gloucester, his third son, eight years of age and who is in their hands' ${ }^{74}$ It might not have been coincidental that on this occasion such stories about the potential for the duke to replace a deposed king emerged at the same time as evidence about the duke's popularity, and in June 1648 one pamphleteer mused that parliament might 'set up Gloucester... as a cipher to please the people' ${ }^{75}$ 
By the winter of 1648/9, however, the thinking may have changed somewhat, and the recent revival of interest in the regicide has raised questions about the motives of those involved in the king's trial, and about whether formal proceedings would necessarily end in his execution, let alone to the abolition of monarchy. ${ }^{76}$ One result of such debates has been consideration of the possibility that Charles's prosecutors sought, or perhaps threatened, his replacement with the duke of Gloucester, and that this influenced the way in which the king behaved during these crucial weeks. On this account, talk of a Henrician succession represented an attempt to weaken the resolve of the king, who understood that crowning his youngest son would 'entrench grandee parliamentarian interests and put in place a child king in whose name any number of affronts to the ancient constitution might be committed'.77 Thus, the Army Remonstrance intimated that the king could be replaced by another member of his family, ${ }^{78}$ and during November 1648 news reports reflected on the possibility - 'some mutter, and it is believed' - that the duke would be set upon the throne, and that during his minority 'great ones will make themselves protectors' ${ }^{79}$ Whitelocke later reflected on a 'secret conclave' that took place in Speaker Lenthall's chamber on 23 December 1648, where the idea resurfaced, and on 6 January 1649 Whitelocke was informed by Ralph Darnall, a parliamentary clerk, that there were stories about people 'drinking to Harry the ninth', even if some believed that such stories and ideas were merely intended to 'fright' the king. ${ }^{80}$ Such ideas, of course, were controversial, and it was also noted that many key people would not 'submit' to a crowned duke of Gloucester. Nevertheless, pamphlets from this period certainly claimed that removing the king would require setting up a new monarch, and noted that 'we have one precious flower and blossom to fix our eyes upon, the duke of Gloucester... who in all probability will speedily be advanced to great honours and dignities, to the great acclamation of the whole kingdom' ${ }^{81}$ As late as 8 January one report suggested that Gloucester would be kept in custody 'as a reserve in case the prince and duke of York should 
prevail so far as to raise any considerable party in the kingdom'. ${ }^{82}$ Indeed, on 26 January, one well-informed royalist intelligencer noted that the children were to be looked after by Sir Henry Mildmay, with the comment that the king's enemies would not 'exchange a king in their power for a king (meaning the prince) out of their power'. ${ }^{83}$ For Sean Kelsey, indeed, Charles I's fear that he might be replaced by the young duke might have encouraged him to consider coming to terms with the new regime, and even recognising the authority of the high court of justice, as perhaps the best way of protecting the monarchy. ${ }^{84}$

The significance of such ideas and stories about a Henrician succession is that they help to make sense of the complex and shifting story of the duke's captivity after the regicide. It has been suggested, therefore, that 'support for the inauguration of a new reign', which might be thought to have been real until the 30 January 1649, 'was not totally eclipsed until the office of king was finally abolished in March 1649', and Kelsey has argued that the determination to prevent a new king from being proclaimed after the regicide reflected concern that this was precisely what might happen by parliamentarians, rather than just royalists. ${ }^{85}$ However, having insisted that nobody should be proclaimed king 'without the consent of the people in parliament' - on the very day that the young duke was granted access to his father (7 January 1649) - it seems clear that talk of monarchy, and perhaps even of the duke being crowned, persisted during the entire period that he was held in captivity. Naturally, such an idea would have been profoundly divisive, and as such it is possible that the events relating to the duke's captivity need to be set against the shifting political landscape of republican England, and the waxing and waning of both radical and moderate forces within the republic.

It might be noteworthy, therefore, that so much of the business relating to the royal children was handled by a small group of powerful grandees, who had been prominent within parliamentarian ranks during the 1640s, who remained prominent during the Rump, and who 
cannot be regarded as having occupied the radical fringes of contemporary thought. These included Northumberland, his sister the countess of Leicester, and her son Lord Lisle, as well as the former courtier Sir Henry Mildmay and his brother, Anthony. Sir Henry Mildmay is intriguing as someone who had opposed a personal treaty with the king in late 1648 apparently saying that the king was 'no more to be trusted than a lion that had been enraged and let loose again at liberty' - but who withdrew from the high court of justice in January 1649 , and refused to sign the death warrant, but who then served on all but one of the republican councils of state. Given the conservatism of this group, it might make sense to suggest that the actions to remove the royal children to Penshurst represented a defensive move prompted by discontent within the army, and debates over the constitution which eventually saw votes to end monarchy (February), and then the passage of an act abolishing the institution, before it was finally resolved that England would be a free state, in May 1649.

It might also be noteworthy that the decision to move the duke to Carisbrooke coincided not just with the with arrival of Charles II in Scotland, and heightened concerns about royalist activity, but also - very precisely - with provocative decisions to destroy statues of Charles I around London, one of which saw 'the head taken off, and the sceptre out of his hand', to be replaced by the inscription 'exit tyrannus, regum ultimus, anno primo libertatis Angliae 1648'. As such, this too may have been a defensive move, prompted by both security fears and heightened radicalism, and it is noteworthy that the move to Carisbrooke was made in the face of calls for the duke to be moved beyond the limits of the commonwealth. Likewise, it seems plausible to argue that moves to release the duke - either by sending him to Scotland or to Heidelberg - reflected the resurgent fortunes of political radicals in the wake of the battle of Dunbar, not least given the involvement of a radical of prominent republicans, such as Chaloner, Scot and Ludlow. Paradoxical as it might seem, it was radicals and republicans who were most obviously involved in attempts to release the 
duke, and political conservatives who sought to keep him in captivity. However, the logic of both positions can perhaps be rationalised: the former wanted to prevent any possibility of the duke being installed on the throne; the latter may have been considering precisely this option.

Moreover, what is also striking is that another period of radical resurgence - in the wake of the battle of Worcester in September 1651 - also seems to have provoked thoughts in at least some quarters about the desirability of some kind of monarchical settlement, and debates that are said to have taken place involving Cromwell, a range of conservative Rumpers (like Whitelocke, Widdrington and St John), as well as more radical figures from the army (Harrison, Fleetwood, Whalley and Disborow). On this occasion, Whitelocke claimed that Cromwell asked 'whether a republic or a mixed monarchical government will be best to be settled', and while the soldiers opposed any move towards monarchy, Whitelocke claimed to have said that 'the laws of England are so interwoven with the power and practice of monarchy that to settle a government without something of monarchy in it would make so great an alteration in the proceeding of our law that you have scarce time to rectify nor can we well foresee the inconvenience which will arise thereby'. Cromwell, moreover, agreed with St John on the desirability of having 'something of monarchical power', noting that 'this will be a business of more than ordinary difficulty', but that 'if it may be done with safety... it would be very effectual'. On this occasion, indeed, Whitelocke apparently mentioned that the duke of Gloucester was 'still among us, and too young to have been in arms against us, or infected with the principles of our enemies'. As such, at least some members of this meeting supported the idea that the duke should 'be made king'. ${ }^{86}$ This meeting - the precise dating of which is unclear - perhaps took place at one of those moments where the possibility of releasing the duke resurfaced, but more striking is the fact that at the precise moment when the council raised the issue of the duke's fate in early September 1652, Cromwell was said to have been preparing to dissolve parliament, call a new representative, and 'by the assistance 
and countenance of it get the duke of Gloucester to be crowned and himself to be declared protector'. ${ }^{87}$ As Worden has noted, of course, nothing came of this idea, 'and the issue of monarchy was quietly dropped', but perhaps it at least helped to provoke the subsequent move to release the duke in the winter of 1652-3, during yet another period when radicalism seemed to be on the rise. ${ }^{88}$

In other words, it seems plausible to suggest that the complex story of the captivity of the duke of Gloucester reflected divisions over the constitution that continued beyond the spring of 1649 , and throughout a period of 'contingency, uncertainty and improvisation' ${ }^{89}$ This saw radicals more or less eager to release him and send him beyond the limits of the commonwealth, Cromwell at least contemplating some kind of monarchical settlement, and moderate or conservative interests keen to keep him within the commonwealth, in case an opportunity arose to effect a constitution with 'something of monarchy' in it, even if only a puppet king. Intriguingly, Charles II's anger at the prospect of the duke being educated as a catholic reflected his concern that 'if the report reaches England, or if any schisms or change of government should occur, the fact would forever prevent the return of his family to their hereditary dominions'. Perhaps Charles II too entertained the vain hope of seeing the 'little duke' on the English throne. ${ }^{90}$

\footnotetext{
${ }^{1}$ BL, M772/15; Penshurst Place, Kent, MS 398: Miles Smyth accounts, 1648-50. Lovell had been tutor to the earl of Sunderland, the countess of Leicester's grandson. See: Edward Hyde, earl of Clarendon, The History of the Rebellion and Civil Wars in England, ed. W. Dunn Macray (6 vols, Oxford, 1888), v. 335.

${ }^{2}$ CSPV 1647-52, p. 90; ODNB.
} 
${ }^{3}$ S. R. Gardiner, The Constitutional Documents of the Puritan Revolution, 1625-1660

(Oxford, 1906), 165, 251.

${ }^{4}$ CSPV 1642-3, pp. 192-3.

${ }^{5}$ S. R. Gardiner, History of the Great Civil War, 1642-1649 (4 vols, 1901), ii. 189; LJ, vii. 279, 327. For payments to Cornelius Holland as paymaster of the princes' household from December 1643 to April 1644, see: TNA, SC6/Chas.1/1661, m.4d.

${ }^{6}$ PA, HL/PO/JO/10/1/167; HL/PO/JO/10/1/184; Mercurius Aulicus, 57 (Feb. 1644), 805.

${ }^{7} C J$, vi. 124.

${ }^{8}$ Clarendon, History of the Rebellion, ed. Macray, v. 335.

${ }^{9}$ CSPV 1647-52, p. 61.

${ }^{10} C J$, vi. 128 .

${ }^{11} C J$, vi. 149.

${ }^{12}$ CSPD 1649-50, p. 76.

${ }^{13} C J$, vi. 193.

${ }^{14}$ CSPD 1649-50, p. 107; CJ, vi. 194-5. Evidence refers to her letters of 22 January and 2 April. The idea that the princess asked for a pension was mentioned by the Venetian ambassador: CSPV 1647-52, p. 107.

${ }^{15}$ CJ, vi. 194-5.

${ }^{16} C J$, vi. 195.

${ }^{17} C J$, vi. 196.

${ }^{18} C J$, vi. 215-16.

${ }^{19}$ Penshurst, MS 398; $C J$, vi. 228-8.

${ }^{20}$ Penshurst, MS 398.

${ }^{21}$ Sydney Papers, ed. R. Blencowe (1825), 75; HMC De L'Isle and Dudley, vi. 589.

22 Penshurst, MS 398. 
${ }^{23}$ Penshurst, MS 398; It is unclear whether all payments in the Penshurst accounts came from government money.

${ }^{24}$ HMC De L'Isle and Dudley, vi. 558.

${ }^{25}$ Clarendon, History of the Rebellion, ed. Macray, iv. 237.

${ }^{26}$ CJ, vi. 231.

${ }^{27}$ Clarendon, History of the Rebellion, ed. Macray, v. 335.

${ }^{28}$ Penshurst, MS 398.

${ }^{29}$ Clarendon, History of the Rebellion, ed. Macray, v. 335.

${ }^{30}$ Perfect Occurrences, 29 (16-23 July 1647), sig. Ff2v; Clarendon, History of the Rebellion, ed. Macray, iv. 250; Calendar of the Clarendon State Papers, ed. W. Macray et al (5 vols, Oxford, 1872-1970), i. 318; CSPV 1647-52, pp. 59-60.

${ }^{31}$ CSPV 1647-52, p. 107.

${ }^{32}$ The Nicholas Papers, ed. G. F. Warner (4 vols, Camden Society, new series, xl, 1, lvii, and $3^{\text {rd }}$ ser., $\left.x x x i, 1886-1920\right)$, i. 165. Hatton described this as 'a business [that] hath slept some while in my hands, but I have not been idle in it, concerning duke of Gloucester', and he blamed the intervention of an unnamed knight, who pretended to be employed by Charles II. That Leicester may have been concerned about the impact of his playing host to the duke on his own fortunes by early 1650 seems clear: HMC De L'Isle and Dudley, vi. 473.

${ }^{33}$ CJ, vi. 231, 446; CSPD 1650, p. 250.

${ }^{34}$ CSPD 1650, pp. 255-6, 257-8, 259, 261, 263, 270, 274. Plate, hangings, bedding and other stuff at Penshurst belonging to state were to be returned. The earl of Leicester noted their departure in his diary: Sydney Papers, ed. Blencowe, 103; HMC De L'Isle and Dudley, vi. 559, 599. Later, Paulucci could note that 'the present place of his confinement remains a secret': CSPV 1647-52, p. 325.

${ }^{35}$ Clarendon, History of the Rebellion, ed. Macray, v. 335. 
${ }^{36}$ Clarendon, History of the Rebellion, ed. Macray, v. 335-6.

${ }^{37}$ CSPD 1650, pp. 258, 261.

${ }^{38}$ CSPD 1650, p. 295.

${ }^{39}$ CJ, vi. 465-6; CSPD 1650, p. 327.

${ }^{40} C J$, vi. 465-6; CSPD 1650, p. 331. For an indication of her popularity, see the following ballad which marked her death: The Lamenting Ladies Last Farewel (1650).

${ }^{41}$ CSPD 1650, p. 328. See: HMC De L'Isle and Dudley, vi. 485.

${ }^{42}$ CJ, vi. 465-6; CSPD 1650, p. 335.

${ }^{43}$ CSPD 1650, p. 344.

${ }^{44}$ CSPD 1650, pp. 357, 366.

${ }^{45}$ CSPD 1650, pp. 368, 379, 394.

${ }^{46}$ CSPD 1650, pp. 392, 405.

${ }^{47}$ CSPD 1650, p. 431. This letter was sent along with Mildmay’s accounts for $£ 312$ spent moving the children from Penshurst to Carisbrooke: CSPD 1650, pp. 440-1; TNA, SP 18/11, ff. 132-3.

${ }^{48}$ CSPD 1650, p. 449.

${ }^{49}$ CSPD 1651, pp. 33, 205, 209, 212, 311; CSPD 1651, p. 235.

${ }^{50}$ CSPD 1651-2, p. 29.

${ }^{51}$ Clarendon, History of the Rebellion, ed. Macray, v. 336.

${ }^{52}$ Clarendon, History of the Rebellion, ed. Macray, v. 336.

${ }^{53}$ CSPD 1650, pp. 394, 405.

${ }^{54}$ CSPD 1651-2, p. 170.

${ }^{55}$ CSPD 1651-2, p. 394; CSPD 1652-3, p. 12.

${ }^{56}$ CJ, vii. 226; CSPD 1652-3, pp. 20, 23.

${ }^{57}$ CSPD 1652-3, pp. 27, 47, 53-4, 56-7, 65; TNA, SP 18/26, f. 108. 
${ }^{58}$ CSPV 1647-52, p. 325.

${ }^{59}$ CSPD 1652-3, p. 56.

${ }^{60}$ CSPD 1652-3, pp. 102-3, 464. This authorised the duke to pass to any port in Flanders in any vessel he chose.

${ }^{61}$ CSPD 1652-3, pp. 141-2.

${ }^{62}$ CSPD 1652-3, pp. 146, 162.

${ }^{63}$ CSPD 1652-3, p. 162.

${ }^{64}$ CSPD 1652-3, p. 163.

${ }^{65}$ CSPD 1652-3, p. 164.

${ }^{66}$ CSPD 1652-3, pp. 221-2; Nicholas Papers, ed. Warner, ii. 5; CSPV 1653-4, pp. 38, 43, 54.

See the duke's letter to Hyde thanking him for his kindness and expressing thankfulness for his escape from England: Calendar of the Clarendon State Papers, ed. Macray et al, ii. 187.

${ }^{67}$ CSPV 1653-4, pp. 77-8; Nicholas Papers, ed. Warner, ii. 7, 8, 11; CSPV 1653-4, p. 283.

${ }^{68}$ Kent History and Library Centre, Maidstone, U269, C267/14; Mercurius Aulicus, 23 (4-10 Oct. 1643), 301-2.

${ }^{69}$ BL, Add. 27962K, f. 417; Gardiner, History of the Great Civil War, ii. 189.

${ }^{70}$ The Diplomatic Correspondence of Jean de Montereul, ed. J. G. Fotheringham (2 vols, Edinburgh, 1898-9), i. 117; Gardiner, History of the Great Civil War, iii. 42-3.

${ }^{71}$ Gardiner, History of the Great Civil War, iii. 130.

${ }^{72}$ Clarendon, History of the Rebellion, ed. Macray, iv, 252. This was why Charles told the duke not to 'accept or suffer himself to be made king whilst either of his elder brothers lived': Clarendon, History of the Rebellion, ed. Macray, iv. 252.

${ }^{73}$ Mercurius Elencticus, 23 (26 Apr.-3 May 1648), 179.

${ }^{74}$ CSPV 1647-52, pp. 59-60. 
${ }^{75}$ Calendar of the Clarendon State Papers, ed. Macray et al, i. 318; Westminster Projects, 6 (1648), 6 .

${ }^{76}$ Sean Kelsey, 'The trial of Charles I', English Historical Review, cxviii.477 (2003), 583616; Sean Kelsey, 'The death of Charles I', Historical Journal, xlv.4 (2002), 727-54; Sean Kelsey, 'Staging the trial of Charles I', in The Regicides and the Execution of Charles I, ed. Jason Peacey (Basingstoke, 2001), 71-93; Clive Holmes, 'The trial and execution of Charles I', Historical Journal, liii.2 (2010), 289-316.

${ }^{77}$ Sean Kelsey, “"The Now King of England”: Conscience, duty and the death of Charles I', English Historical Review, cxxxii.558 (2017), 1099-1100.

${ }^{78}$ A Remonstrance from the Army (1648), 65-7; An Abridgment of the Late Remonstrance (1648), 3, 6 .

${ }^{79}$ Bodl. MS Clarendon 31, f. 312; BL, Add. 78221, f. 24.

${ }^{80}$ David Underdown, Pride's Purge: Politics in the Puritan Revolution (Oxford, 1971), 170, 183; Bulstrode Whitelocke, Memorials of the English Affairs (4 vols, Oxford, 1853), iii. 47981; Longleat House, Whitelocke Papers, x, f. 1; Mercurius Pragmaticus, 40/41 (26 Dec. 1648-9 Jan. 1649), sig. Fff3.

${ }^{81}$ The Queens Majesties Letter to the Parliament of England (1649), 3, 5.

${ }^{82}$ Bodl. MS Clarendon 34, f. $72 \mathrm{v}$.

${ }^{83}$ Bodl. MS Clarendon 34, ff. 86-7.

${ }^{84}$ Kelsey, 'The Now King of England', 1098-9, 1100-1101, 1104.

${ }^{85}$ Sean Kelsey, 'The foundation of the council of state', in Parliament at Work, ed. Chris R. Kyle and Jason Peacey (Woodbridge, 2002), 138-41; Kelsey, 'The Now King of England', 1100. 
${ }^{86}$ Blair Worden, The Rump Parliament, 1648-1653 (Cambridge, 1974), 276-7; The Writings and Speeches of Oliver Cromwell, ed. Wilbur Cortez Abbott (4 vols, Cambridge, Mass., 1937-47), ii. 505-7; Whitelocke, Memorials, iii. 372-4; Underdown, Pride’s Purge, 292.

${ }^{87}$ Nicholas Papers, ed. Warner, i. 310.

${ }^{88}$ Worden, Rump Parliament, 277.

${ }^{89}$ Kelsey, 'The Now King of England', 1108.

${ }^{90} \operatorname{CSPV} 1653-4$, p. 283. 